
\title{
.
}

\section{Inhibitory Effect of $\mathrm{NH}_{4} \mathrm{Cl}$ Treatment on Renal TgfB1 Signaling Following Unilateral Ureteral Obstruction}

\author{
Martina Feger Ioana Alesutan Tatsiana Castor Sobuj Mia Katharina Musculus \\ Jakob Voelkl Florian Lang \\ Department of Physiology, University of Tuebingen, Tuebingen, Germany
}

\section{Key Words}

Unilateral ureteral obstruction $\bullet \mathrm{NH}_{4} \mathrm{Cl} \cdot \operatorname{Tgf} \beta 1 \cdot \operatorname{Sox} 9 \cdot$ Renal fibrosis

\begin{abstract}
Background/Aims: Consequences of obstructive nephropathy include tissue fibrosis, a major pathophysiological mechanism contributing to development of end-stage renal disease. Transforming growth factor $\beta 1$ (Tgf $\beta 1)$ is involved in the progression of renal fibrosis. According to recent observations, ammonium chloride $\left(\mathrm{NH}_{4} \mathrm{Cl}\right)$ prevented phosphate-induced vascular remodeling, effects involving decrease of Tgf $\beta 1$ expression and inhibition of Tgf $\beta 1$-dependent signaling. The present study, thus, explored whether $\mathrm{NH}_{4} \mathrm{Cl}$ influences renal Tgf $\beta 1$-induced profibrotic signaling in obstructive nephropathy induced by unilateral ureteral obstruction (UUO). Methods: UUO was induced for seven days in C57BI6 mice with or without additional treatment with $\mathrm{NH}_{4} \mathrm{Cl}(0.28 \mathrm{M}$ in drinking water). Transcript levels were determined by RT-PCR as well as protein abundance by Western blotting, blood $\mathrm{pH}$ was determined utilizing a blood gas and chemistry analyser. Results: UUO increased renal mRNA expression of Tgfb1, Tgf $\beta$-activated kinase 1 (Tak1) protein abundance and Smad2 phosphorylation in the nuclear fraction of the obstructed kidney tissues, effects blunted in $\mathrm{NH}_{4} \mathrm{Cl}$ treated mice as compared to control treated mice. The mRNA levels of the transcription factors nuclear factor of activated T cells 5 (Nfat5) and SRY (sex determining region Y)-box 9 (Sox9) as well as of tumor necrosis factor $\alpha$ (Tnfo), interleukin 6 (Il6), plasminogen activator inhibitor 1 (Pai1) and Snai1 were up-regulated in the obstructed kidney tissues following UUO, effects again significantly ameliorated following $\mathrm{NH}_{4} \mathrm{Cl}$ treatment. Furthermore, the increased protein and mRNA expression of $\alpha$-smooth muscle actin $(\alpha-S m a)$, fibronectin and collagen type I in the obstructed kidney tissues following UUO were significantly attenuated following $\mathrm{NH}_{4} \mathrm{Cl}$ treatment. Conclusion: $\mathrm{NH}_{4} \mathrm{Cl}$ treatment ameliorates Tgf $\beta 1$-dependent pro-fibrotic signaling and renal tissue fibrosis markers following obstructive nephropathy.
\end{abstract}

Copyright (C) 2015 S. Karger AG, Basel

Prof. Dr. Florian Lang

KARGER 125
Department of Physiology, University of Tuebingen,

Gmelinstr. 5, 72076 Tuebingen, (Germany)

Tel. +4970712972194, Fax+497071295618, E-Mail florian.lang@uni-tuebingen.de 


\begin{tabular}{|c|c|c|}
\hline Cellular Physiology & Cell Physiol Biochem 2015;37:955-964 & \\
\hline and Biochemistry & $\begin{array}{l}\text { DOI: } 10.1159 / 000430222 \\
\text { Published online: September 23, } 2015\end{array}$ & $\begin{array}{l}\text { O } 2015 \mathrm{~S} \text {. Karger AG, Basel } \\
\text { www.karger.com/cpb }\end{array}$ \\
\hline
\end{tabular}

\section{Introduction}

Renal fibrosis, particularly tubulointerstitial fibrosis, is a common pathophysiological pathway of several renal diseases leading to end-stage renal failure [1-3]. Renal fibrosis contributes to the pathophysiology of chronic kidney disease [1,3]. Tubulointerstitial fibrosis is characterized by excessive accumulation of extracellular matrix (ECM) proteins, such as $\alpha$-smooth muscle actin ( $\alpha$-Sma), collagen type I and fibronectin, leading to destruction of the functional tissue $[1,3,4]$. The increased production and deposition of ECM is mainly caused by myofibroblasts [5], which may be recruited from resident fibroblasts, bone marrowderived cells or from epithelial to mesynchymal transition (EMT) [5, 6].

Mechanisms involved in the regulation of ECM protein expression leading finally to ECM deposition include transforming growth factor $\beta 1$ (Tgf $\beta 1$ ) $[1,3,4]$. Tgf $\beta 1$ signaling seems to be a major pathway inducing fibroblast activation and proliferation [7]. In renal fibrosis, Tgf $\beta 1$-induced EMT is mediated via Smad2/3 phosphorylation and subsequent nuclear translocation [3]. Activation of the Tgf $\beta 1 /$ Smad pathway up-regulates plasminogen activator inhibitor 1 (Pai1) which is closely linked to the development of EMT and ECM deposition [3]. In addition to activation of Smad-dependent signaling pathways, Tgf $\beta 1$ activates various Smad-independent pathways to induce its pro-fibrotic effects [7]. Tgf $\beta$-activated kinase 1 (Tak1) has been identified as a major non-canonical signaling molecule in Tgf $\beta 1$-mediated fibrosis [7]. Moreover, Tak1 participates in the regulation of Tgf $\beta 1$-induced activation of Smads [7].

Tgf $\beta 1$, tumor necrosis factor $\alpha(\operatorname{Tnf} \alpha)$ and Pai 1 are further implicated in excessive vascular remodeling, osteoinductive signaling and subsequent vascular calcification in klotho deficiency $[8,9]$. According to recent observations, ammonium chloride $\left(\mathrm{NH}_{4} \mathrm{Cl}\right)$ treatment prevented tissue calcification and reduced vascular senescence in klotho-hypomorphic mice [8]. In those mice, the excessive expression of $\mathrm{Tg} f \mathrm{~b} 1$, transcription factor nuclear factor of activated T cells 5 ( Nfat5), Nfat5-downstream mediator SRY (sex determining region Y)-box 9 (Sox9) and Pai1 was reversed following $\mathrm{NH}_{4} \mathrm{Cl}$ treatment. $\mathrm{NH}_{4} \mathrm{Cl}$ has previously been shown to interfere with Tgf $\beta 1$ [10]. Moreover, the expression of $\operatorname{Sox} 9$, a transcriptional regulator in the development of tissue fibrosis [11] was shown to be regulated by Tgf $\beta 1$ [12] and Tak1 [13].

The present study thus explored the effect of $\mathrm{NH}_{4} \mathrm{Cl}$ treatment on renal Tgf $\beta 1$-dependent signaling and markers of fibrosis following obstructive nephropathy. To this end, mice were subjected to unilateral ureteral obstruction (UUO), a well established model to induce tubulointerstitial fibrosis $[2,14]$, with or without $\mathrm{NH}_{4} \mathrm{Cl}$ treatment added to the drinking water [8].

\section{Materials and Methods}

Animals

All animal experiments were conducted according to the German law for the welfare of animals and were approved by local authorities. Experiments have been performed in male mice (C57Bl6) at the age of 8 weeks. Mice had free access to food (Sniff) and tap drinking water. Where indicated, $\mathrm{NH}_{4} \mathrm{Cl}(0.28 \mathrm{M})$ was added to the drinking water 3 days before the surgical intervention and for the duration of the UUO treatment.

Unilateral ureteral obstruction

Renal fibrosis was induced by unilateral ureteral obstruction (UUO) [2]. Following surgical incision of the skin and abdominal wall, the left ureter was exposed and ligated twice with a non-resorbable 7-0 filament. Following ligation the surgical wound was closed by sutures. Mice were treated with metamizole for analgesia (200 mg/kg body weight) after the procedure and for the duration of the UUO experiment in drinking water. The mice were sacrificed 7 days after the ligation procedure and the obstructed as well as the non-obstructed kidney were rapidly removed and kidney tissues snap frozen in liquid nitrogen. 


\section{Cellular Physiology Cell Physiol Biochem 2015;37:955-964

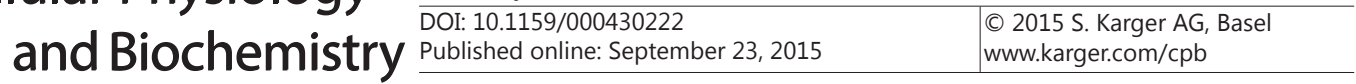 \\ Feger et al.: $\mathrm{NH}_{4} \mathrm{Cl}$ and Renal Tgf $\beta 1$}

Blood pH analysis

For blood pH analysis, the retro-orbital plexus was punctured with a heparinized capillary. The blood samples were injected directly from the capillary into a blood gas analyzer (i15 blood gas and chemistry analyzer, Edan) to determine blood $\mathrm{pH}$.

Quantitative RT-PCR

Total RNA was isolated from murine kidney tissues using Trifast Reagent (Peqlab) according to the manufacturer's instructions. Reverse transcription of $2 \mu \mathrm{g}$ RNA was performed using oligo(dT) ${ }_{12-18}$ primers (Invitrogen) and SuperScript III Reverse Transcriptase (Invitrogen). Quantitative real-time PCR was performed with the iCycler $\mathrm{iQ}^{\mathrm{TM}}$ Real-Time PCR Detection System (Bio-Rad Laboratories) and iQSybr Green Supermix (Bio-Rad Laboratories) according to the manufacturer's instructions. The following primers were used ( $5^{\prime} \rightarrow 3^{\prime}$ orientation):

$a$-Sma fw: CCCAGACATCAGGGAGTAATGG;

a-Sma rev: CTATCGGATACTTCAGCGTCA;

Col1a1f w: ACCCGAGGTATGCTTGATCTG;

Col1a1 rev: CATTGCACGTCATCGCACAC;

Fbn fw: GTGACACTTATGAGCGCCCTA;

Fbn rev: CCACTTGTCGCCAATCTTGTA;

Gapdh fw: AGGTCGGTGTGAACGGATTTG;

Gapdh rev: TGTAGACCATGTAGTTGAGGTCA;

Il6 fw: TCTATACCACTTCACAAGTCGGA;

Il6 rev: GAATTGCCATTGCACAACTCTTT;

Nfat5 fw: GAGGGGTGTGGATTGGAATCT;

Nfat5 rev: CTGGTGCTCATGTTACTGAAGTT;

Pai1 fw: TTCAGCCCTTGCTTGCCTC;

Pai1 rev: ACACTTTTACTCCGAAGTCGGT;

Snai1 fw: CACACGCTGCCTTGTGTCT;

Snai1 rev: GGTCAGCAAAAGCACGGTT;

Sox9 fw: AGTACCCGCATCTGCACAAC;

Sox9 rev: ACGAAGGGTCTCTTCTCGCT;

Tgfb1 fw: CTCCCGTGGCTTCTAGTGC;

Tgfb1 rev: GCCTTAGTTTGGACAGGATCTG;

Tnfa fw: CTGAACTTCGGGGTGATCGG;

Tnfa rev: GGCTTGTCACTCGAATTTTGAGA.

The specificity of the PCR products was confirmed by analysis of the melting curves. All PCRs were performed in duplicate and relative mRNA fold changes were calculated by the $2^{-\Delta \Delta \mathrm{Ct}}$ method using Gapdh as internal reference. Results are shown normalized to the mRNA expression in obstructed kidney tissues of control treated mice.

Extraction of nuclear and cytoplasmic proteins

Cytoplasmic and nuclear extracts were prepared using the NE-PER nuclear and cytoplasmic extraction reagents (Thermo Fisher Scientific) according to the manufacturer's instructions. Protein concentration was determined by Bradford assay (Biorad Laboratories) and $20 \mu \mathrm{g}$ of protein were boiled in Roti-Load1 Buffer (Carl Roth) at $100^{\circ} \mathrm{C}$ for $5 \mathrm{~min}$. Smad2 phosphorylation in the nuclear and cytoplasmic fractions were further determined by Western blot analysis.

Western blot analysis

Murine kidney tissues were lysed with ice-cold lysis buffer (Thermo Fisher Scientific) supplemented with complete protease and phosphatase inhibitor cocktail (Thermo Fisher Scientific). After centrifugation at $10000 \mathrm{rpm}$ for $5 \mathrm{~min}$, proteins were boiled in Roti-Load1 Buffer (Carl Roth) at $100^{\circ} \mathrm{C}$ for $5 \mathrm{~min}$. Proteins were separated on SDS-polyacrylamide gels and transferred to PVDF membranes. The membranes were incubated overnight at $4^{\circ} \mathrm{C}$ with the following primary antibodies: rabbit anti- $\alpha$-smooth muscle actin, rabbit anti-collagen I (diluted 1:1000, Abcam), mouse anti-fibronectin (diluted 1:1000, BD Biosciences), rabbit anti-Tak1, rabbit anti-Smad2, rabbit anti-phosphorylated Smad2 (Ser ${ }^{465 / 467}$, diluted 1:1000, Cell Signaling), 


\begin{tabular}{|c|c|c|}
\hline Cellular Physiology & Cell Physiol Biochem 2015;37:955-964 & \\
\hline and Biochemistry & $\begin{array}{l}\text { DOI: } 10.1159 / 000430222 \\
\text { Published online: September 23, } 2015\end{array}$ & $\begin{array}{l}\text { O } 2015 \mathrm{~S} \text {. Karger AG, Basel } \\
\text { www.karger.com/cpb }\end{array}$ \\
\hline
\end{tabular}

rabbit anti- $\alpha$-tubulin and rabbit anti-Gapdh antibody (diluted 1:2000, Cell Signaling) and then with secondary goat anti-rabbit HRP-conjugated antibody (diluted 1:2000, Cell Signaling) or goat anti-mouse HRP-conjugated antibody (diluted 1:2000, Cell Signaling) for 1 hour at room temperature. For loading controls, the membranes were stripped with stripping buffer (Carl Roth) at $60^{\circ} \mathrm{C}$ for 10 min. Antibody binding was detected with the ECL detection reagent (Thermo Fisher Scientific). Bands were quantified with Quantity One Software (Bio-Rad Laboratories) and results are shown as the ratio of total protein to Gapdh. For cytoplasmic and nuclear phosphorylated Smad2, results are shown as the ratio of phosphorylated to total Smad2 to Hdac2 or $\alpha$-tubulin protein for the nuclear fraction or the cytoplasmic fraction, respectively.

\section{Statistics}

Data are provided as means $\pm \mathrm{SEM}, n$ represents the number of independent experiments. All data were tested for significance between control and $\mathrm{NH}_{4} \mathrm{Cl}$ treated mice using unpaired Student $t$-test (normal distributed data) or Mann-Whitney test (non-normal distributed data) according to Shapiro-Wilk test. Only results with $p<0.05$ were considered statistically significant.

\section{Results}

To explore whether $\mathrm{NH}_{4} \mathrm{Cl}$ treatment influences renal pro-fibrotic signaling following obstructive nephropathy, UUO was performed in C57Bl6 mice with or without additional treatment with $\mathrm{NH}_{4} \mathrm{Cl}$. The mice were treated with $0.28 \mathrm{M} \mathrm{NH}_{4} \mathrm{Cl}$ in the drinking water 3 days before the obstructive injury and for the duration of the UUO treatment. Seven days after the obstructive injury, the animals were sacrificed and the obstructed kidney tissues were compared between the treatment groups. $\mathrm{NH}_{4} \mathrm{Cl}$ treatment significantly $(\mathrm{p}<0.01)$ decreased blood $\mathrm{pH}$ from $7.37 \pm 0.03$ to $7.20 \pm 0.04(\mathrm{n}=5)$.

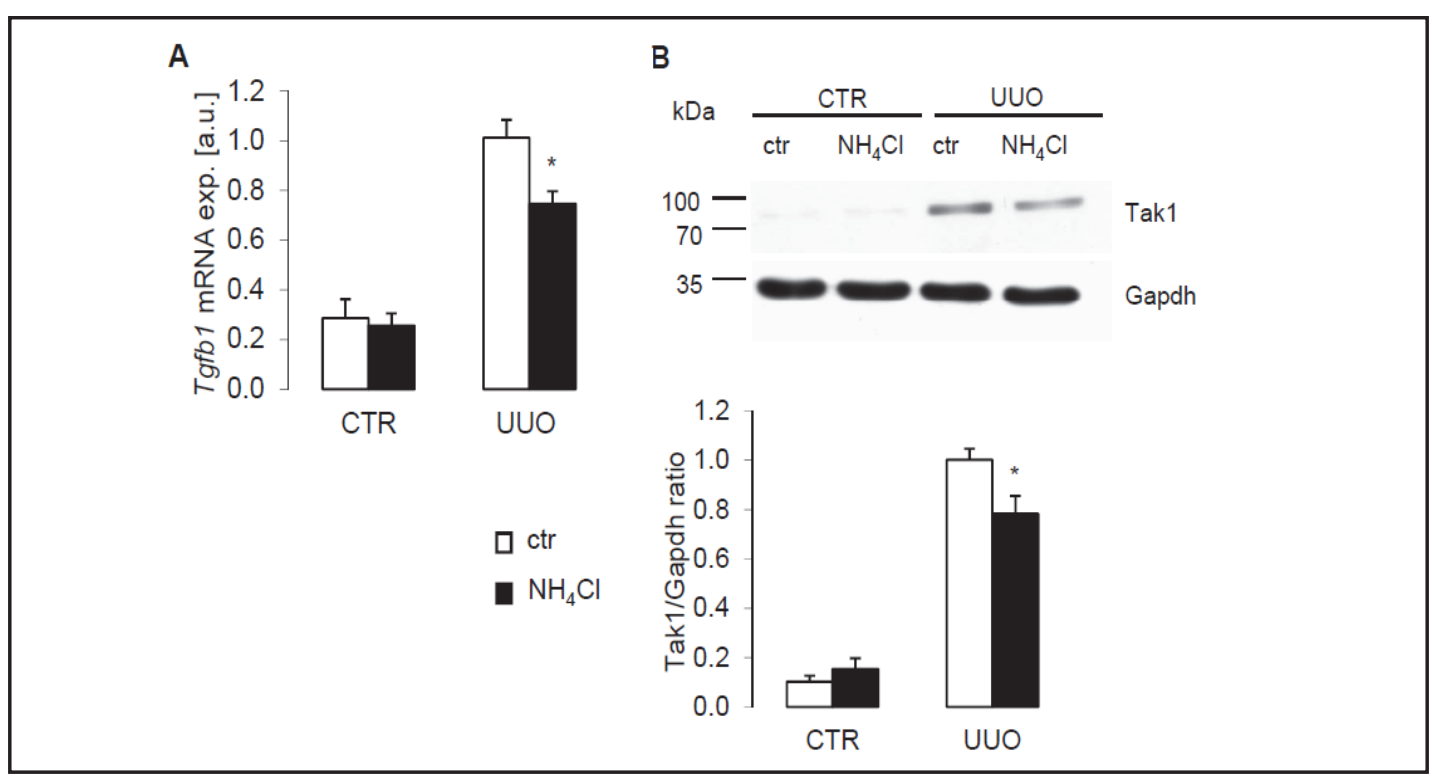

Fig. 1. Effect of $\mathrm{NH}_{4} \mathrm{Cl}$ treatment on UUO-induced Tgf $\beta 1$ and Tgf $\beta$-activated kinase 1 (Tak1) expression in renal tissue. (A) Arithmetic means \pm SEM $(n=6)$ of transforming growth factor $\beta 1(\mathrm{Tg} f b 1)$ relative mRNA expression (arbitrary units, a.u.) in renal tissue from non-obstructed control kidney (CTR) and obstructed kidney (UUO) following 7 days of unilateral ureteral obstruction (UUO) in control treated mice (ctr; white bars) and in mice treated with $\mathrm{NH}_{4} \mathrm{Cl}\left(0.28 \mathrm{M} \mathrm{NH}_{4} \mathrm{Cl}\right.$ added to the drinking water; black bars). (B) Representative original western blots and arithmetic means \pm SEM $(n=9)$ showing Tgf $\beta$-activated kinase 1 (Tak1)/Gapdh protein ratio in renal tissue from non-obstructed control kidney (CTR) and obstructed kidney (UUO) following 7 days of unilateral ureteral obstruction (UUO) in control treated mice (ctr; white bars) and in mice treated with $\mathrm{NH}_{4} \mathrm{Cl}\left(0.28 \mathrm{M} \mathrm{NH}_{4} \mathrm{Cl}\right.$ added to the drinking water; black bars $) .{ }^{*}(\mathrm{p}<0.05)$ statistically significant vs respective kidney tissues of control treated mice.

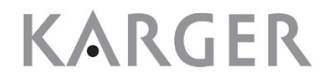




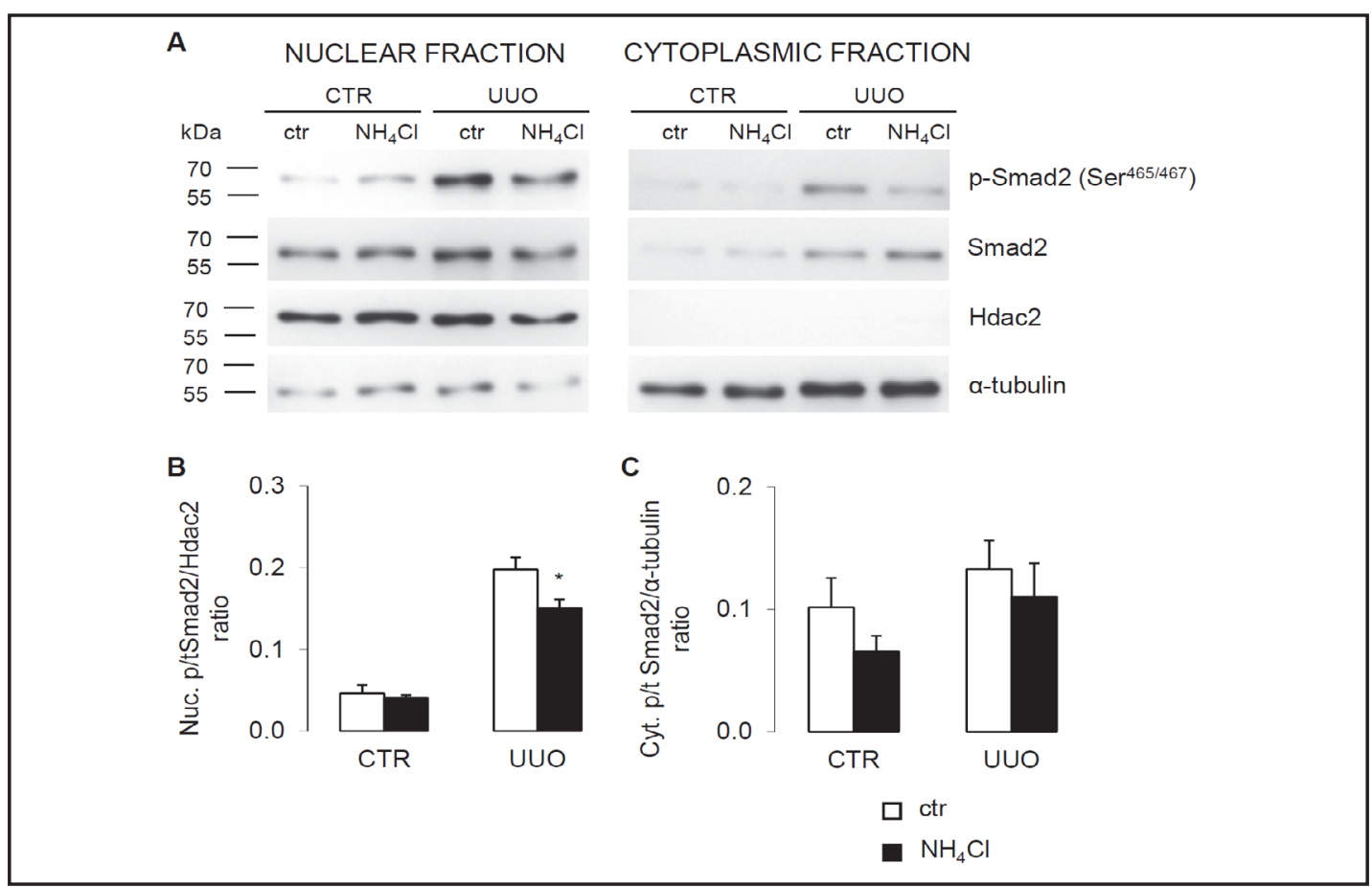

Fig. 2. Impact of $\mathrm{NH}_{4} \mathrm{Cl}$ treatment on nuclear and cytoplasmic Smad2 phosphorylation in renal tissue following unilateral ureteral obstruction. (A) Representative original western blots showing phospho-Smad2 (Ser ${ }^{465 / 467}$ ), Smad2, Hdac2 and $\alpha$-tubulin protein abundance in nuclear and cytoplasmic fractions of renal tissue from nonobstructed control kidney (CTR) and obstructed kidney (UUO) following 7 days of unilateral ureteral obstruction (UUO) in control treated mice (ctr) and in mice treated with $\mathrm{NH}_{4} \mathrm{Cl}\left(0.28 \mathrm{M} \mathrm{NH}_{4} \mathrm{Cl}\right.$ added to the drinking water). (B, C) Arithmetic means \pm SEM ( $\mathrm{n}=7$ ) of nuclear (Nuc, B) and cytoplasmic (Cyt, C) phospho-Smad2 $\left(\operatorname{Ser}^{465 / 467}\right) / \mathrm{Smad} 2$ to Hdac2 or $\alpha$-tubulin protein ratio in the nuclear fraction and cytoplasmic fraction respectively, in renal tissue from non-obstructed control kidney (CTR) and obstructed kidney (UUO) following 7 days of unilateral ureteral obstruction (UUO) in control treated mice (ctr; white bars) and in mice treated with $\mathrm{NH}_{4} \mathrm{Cl}\left(0.28 \mathrm{M} \mathrm{NH}_{4} \mathrm{Cl}\right.$ added to the drinking water; black bars $) .{ }^{*}(\mathrm{p}<0.05)$ statistically significant vs respective kidney tissues of control treated mice.

Based on previous observations, Tgf $\beta 1$ signaling was investigated in renal obstructive injury. As shown in Fig. 1A, Tgfb1 mRNA expression was higher in the obstructed kidney tissues than in non-obstructed control kidney tissues following UUO. The increased Tgfb1 mRNA levels were significantly decreased in the obstructed kidney tissues from $\mathrm{NH}_{4} \mathrm{Cl}$ treated mice as compared to control treated mice (Fig. 1A). The effects of $\mathrm{NH}_{4} \mathrm{Cl}$ treatment on renal $\mathrm{Tgfb} 1$ expression were paralled by a significant reduction of the increased Tak1 protein levels in the obstructed kidney tissues (Fig. 1B). Moreover, the increased Smad2 phosphorylation at $\mathrm{Ser}^{465 / 467}$ in the nuclear fraction isolated from obstructed kidney tissues following UUO was significantly decreased in $\mathrm{NH}_{4} \mathrm{Cl}$ treated mice as compared to control treated mice (Fig. 2A, B). No significant effects of $\mathrm{NH}_{4} \mathrm{Cl}$ treatment on Smad2 phosphorylation in the cytoplasmic fraction isolated from the obstructed kidney tissues were observed (Fig. 2A, C). In nonobstructed control kidney tissues, $\mathrm{NH}_{4} \mathrm{Cl}$ treatment did not significantly modify $\mathrm{Tg} f b 1$ and Tak1 expression (Fig. 1) or Smad2 phosphorylation (Fig. 2).

To further define the effects of $\mathrm{NH}_{4} \mathrm{Cl}$ on Tgf $\beta 1$-mediated pro-fibrotic signaling following UUO, the mRNA expression of the transcription factors Nfat5 and Sox 9 was determined. Following UUO, Nfat5 and Sox 9 mRNA levels were increased in the obstructed kidney tissues as compared to non-obstructed control kidney tissues, effects significantly suppressed following treatment with $\mathrm{NH}_{4} \mathrm{Cl}$ (Fig. $3 \mathrm{~A}, \mathrm{~B}$ ). $\mathrm{NH}_{4} \mathrm{Cl}$ treatment did not significantly modify Nfat5 and Sox 9 mRNA levels in the non-obstructed control kidney tissues (Fig. 3A, B). 
A

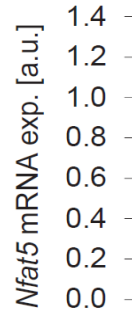

CTR
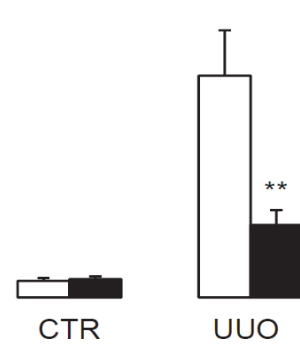

B

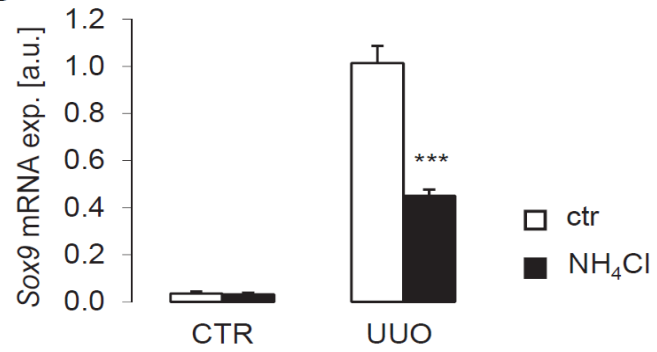

Fig. 3. Effect of $\mathrm{NH}_{4} \mathrm{Cl}$ on renal $\mathrm{Nfat} 5$ and $\operatorname{Sox} 9$ mRNA expression following unilateral ureteral obstruction. Arithmetic means \pm SEM $(n=6)$ of nuclear factor of activated T cells 5 (Nfat5; A) and SRY (sex determining region Y)-box 9 (Sox9; B) relative mRNA expression (arbitrary units; a.u.) in renal tissue from non-obstructed control kidney (CTR) and obstructed kidney (UUO) following 7 days of unilateral ureteral obstruction (UUO) in control treated mice (ctr; white bars) and in mice treated with $\mathrm{NH}_{4} \mathrm{Cl}\left(0.28 \mathrm{M} \mathrm{NH}_{4} \mathrm{Cl}\right.$ added to the drinking water; black bars). ${ }^{* *}(\mathrm{p}<0.01),{ }^{* * *}(\mathrm{p}<0,001)$ statistically significant vs respective kidney tissues of control treated mice.

A

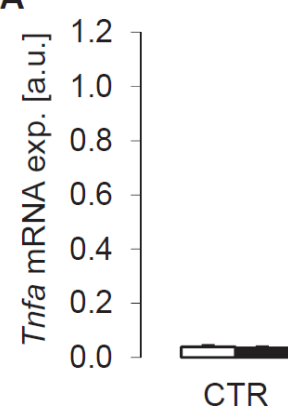

C

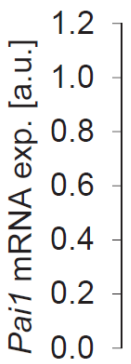

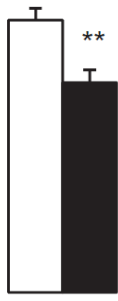

UUO
B

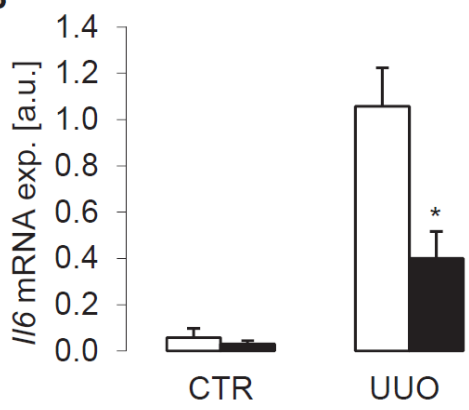

D

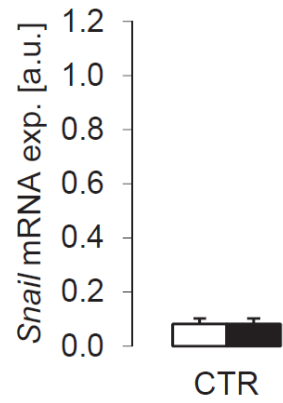

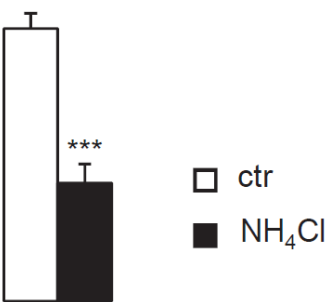

UUO

Fig. 4. $\mathrm{NH}_{4} \mathrm{Cl}$ sensitive expression of Tgf $\beta 1$ target genes in renal tissue following unilateral ureteral obstruction. Arithmetic means \pm SEM $(n=6)$ of tumor necrosis factor $\alpha(\operatorname{Tnfa}$; A), interleukin 6 (Il6; B), plasminogen activator inhibitor 1 (Pai1; C) and Snai1 (D) relative mRNA expression (arbitrary units, a.u.) in renal tissue from non-obstructed control kidney (CTR) and obstructed kidney (UUO) following 7 days of unilateral ureteral obstruction (UUO) in control treated mice (ctr; white bars) and in mice treated with $\mathrm{NH}_{4} \mathrm{Cl}\left(0.28 \mathrm{M} \mathrm{NH}_{4} \mathrm{Cl}\right.$ added to the drinking water; black bars). ${ }^{*}(\mathrm{p}<0.05),{ }^{* *}(\mathrm{p}<0.01),{ }^{* * *}(\mathrm{p}<0,001)$ statistically significant vs respective kidney tissues of control treated mice.

Further experiments addressed the transcript levels of Tgf $\beta 1$ target genes: Tnfa, the cytokine Il6, as well as of Pai1and Snai1. As shown in Fig. 4, the increased mRNA expression of Tnfa, Il6, Pai1 and Snai1 in obstructed kidney tissues following UUO were all significantly reduced in $\mathrm{NH}_{4} \mathrm{Cl}$ treated mice as compared to control treated mice. $\mathrm{NH}_{4} \mathrm{Cl}$ treatment did not 


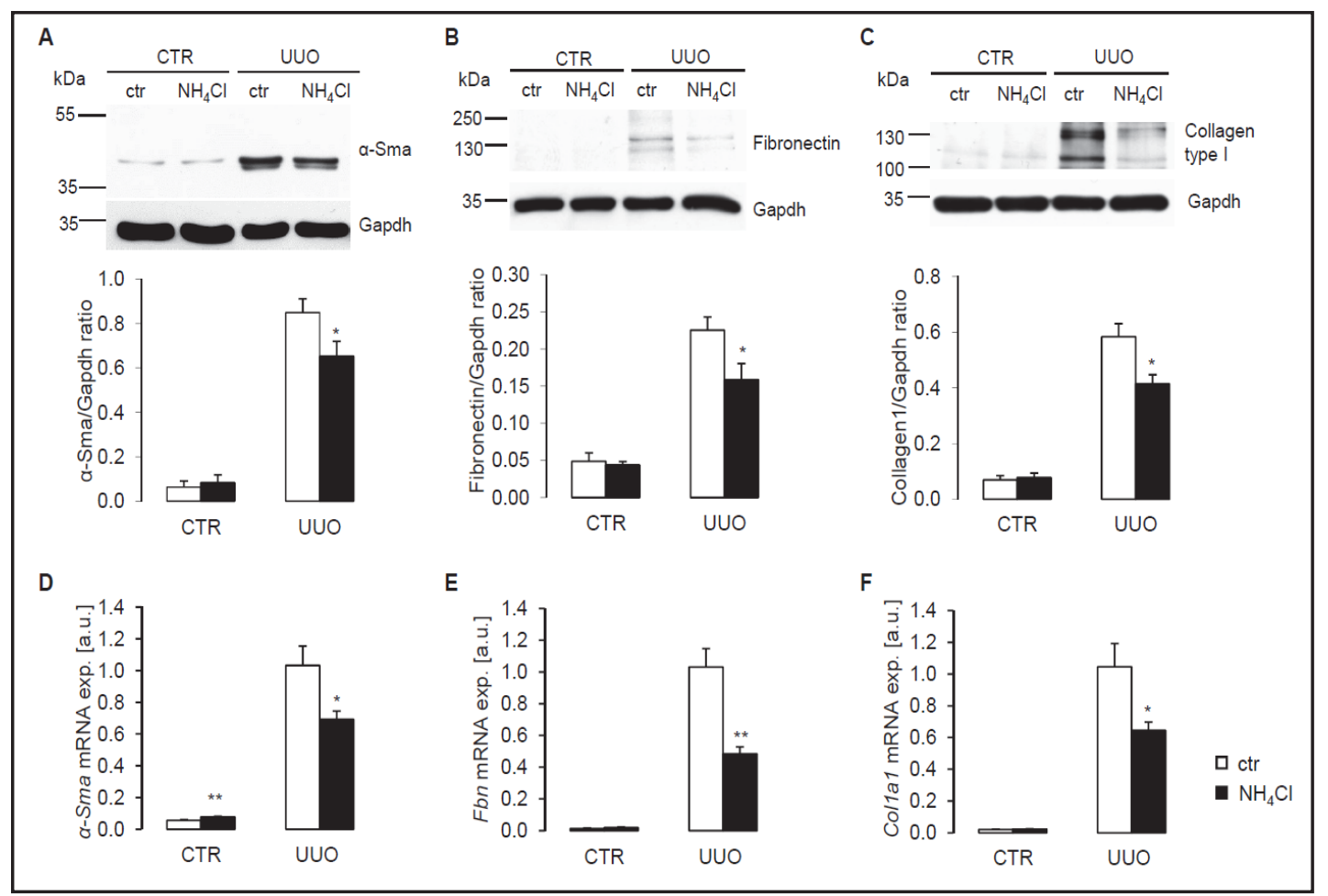

Fig. 5. $\mathrm{NH}_{4} \mathrm{Cl}$ treatment ameliorates the expression of $\alpha$-smooth muscle actin, fibronectin and collagen type 1 in renal tissue following unilateral ureteral obstruction. (A-C) Representative original western blots and arithmetic means \pm SEM $(n=9)$ of $\alpha$-smooth muscle actin $(\alpha$-Sma)/Gapdh $(A)$, fibronectin/Gapdh (B) and collagen type I/Gapdh (C) protein ratio in renal tissue from non-obstructed control kidney (CTR) and obstructed kidney (UUO) following 7 days of unilateral ureteral obstruction (UUO) in control treated mice (ctr; white bars) and in mice treated with $\mathrm{NH}_{4} \mathrm{Cl}\left(0.28 \mathrm{M} \mathrm{NH}_{4} \mathrm{Cl}\right.$ added to the drinking water; black bars). (D-F) Arithmetic means \pm SEM ( $n=6)$ of $\alpha$-smooth muscle actin ( $\alpha$-Sma; D), fibronectin (Fbn; E) and collagen type 1 (Col1a1; F) relative mRNA expression (arbitrary units, a.u.) in renal tissue from non-obstructed control kidney (CTR) and obstructed kidney (UUO) following 7 days of unilateral ureteral obstruction (UUO) in control treated mice (ctr; white bars) and in mice treated with $\mathrm{NH}_{4} \mathrm{Cl}\left(0.28 \mathrm{M} \mathrm{NH}_{4} \mathrm{Cl}\right.$ added to the drinking water; black bars $) .{ }^{*}(\mathrm{p}<0.05),{ }^{* *}$ $(p<0.01)$ statistically significant vs respective kidney tissues of control treated mice.

significantly modify Tnfa, Il6, Pai1 and Snai1 mRNA expression in the non-obstructed control kidney tissues (Fig. 4).

In order to quantify the effect of $\mathrm{NH}_{4} \mathrm{Cl}$ treatment on markers of the fibrotic response following UUO, the expression of $\alpha$-Sma, fibronectin and collagen type I was determined. As a result, the increased $\alpha$-Sma (Fig. 5A), fibronectin (Fig. 5B) and collagen type I (Fig. 5C) protein expression in obstructed kidney tissues following UUO were significantly reduced in $\mathrm{NH}_{4} \mathrm{Cl}$ treated mice as compared to control treated mice. Accordingly, $\mathrm{NH}_{4} \mathrm{Cl}$ treatment significantly blunted the increased renal mRNA expression of $\alpha$-Sma (Fig. 5D), fibronectin (Fbn) (Fig. 5E) and collagen type I (Col1a1) (Fig. 5F) in obstructed kidney tissues following UUO. In non-obstructed control kidney tissues, $\mathrm{NH}_{4} \mathrm{Cl}$ treatment did not significantly affect renal $\alpha$-Sma, fibronectin and collagen type I protein expression and Fbn and Col1a1 mRNA levels but significantly increased renal $\alpha$-Sma mRNA expression (Fig. 5).

\section{Discussion}

The present study reveals a suppressive effect of $\mathrm{NH}_{4} \mathrm{Cl}$ treatment on the signaling of renal interstitial fibrosis following UUO. $\mathrm{NH}_{4} \mathrm{Cl}$ treatment significantly blunted the increase of renal 
$\alpha$-Sma, a mesenchymal marker mainly expressed by activated fibroblasts and myofibroblasts [5]. Consistent with reduced $\alpha$-Sma abundance following obstructive injury, renal expression of ECM proteins such as fibronectin and collagen type 1 were mitigated in the mice treated with $\mathrm{NH}_{4} \mathrm{Cl}$.

In the development of renal fibrosis, Tgf $\beta 1$ is regarded as the most relevant pro-fibrotic cytokine [7]. Similar to previous findings [8], $\mathrm{NH}_{4} \mathrm{Cl}$ treatment inhibited UUO-induced upregulation of $\mathrm{Tg} f b 1 \mathrm{mRNA}$ expression in the obstructed kidney tissues. Dietary treatment with $\mathrm{NH}_{4} \mathrm{Cl}$ leads to acidosis [15]. Moreover, $\mathrm{NH}_{4}{ }^{+}$may further dissociate to $\mathrm{H}^{+}$and $\mathrm{NH}_{3}$, which permeates membranes and thus enters cells and cellular compartments [16]. $\mathrm{NH}_{3}$ may bind $\mathrm{H}^{+}$and may thus be trapped as $\mathrm{NH}_{4}^{+}$within acidic cellular compartments [17]. The binding of $\mathrm{H}^{+}$alkalinizes those compartments [17]. By alkalinizing lysosomes, $\mathrm{NH}_{4} \mathrm{Cl}$ has previously been shown to interfere with $\operatorname{Tgf} \beta 1$ maturation [10].

The effects of $\mathrm{NH}_{4} \mathrm{Cl}$ on Tgfb1 expression were paralleled by inhibition of increased Tak1 protein levels and of increased nuclear phosphorylated Smad2, downstream signaling mediators of $\mathrm{Tgf} \beta 1[3,18]$. Moreover, $\mathrm{NH}_{4} \mathrm{Cl}$ treatment reduces the increased expression of the pro-fibrotic Tgf $\beta 1$ target genes: Tnfa, Il6, Pai1 and Snai1 following obstructive injury.

Beyond that, the cellular accumulation of $\mathrm{NH}_{4}^{+}$with $\mathrm{Cl}^{-}$may lead to cell swelling [19] which suppresses expression of the cell volume sensitive transcription factor TONEBP (Tonicity-Responsive Enhancer Binding Protein) or Nfat5 [20]. Accordingly, $\mathrm{NH}_{4} \mathrm{Cl}$ treatment significantly blunted UUO-induced renal Nfat5 expression. Tgf $\beta 1$ up-regulates Nfat5 expression [21]. Nfat5 was in turn shown to up-regulate Tnf $\alpha$ and Il6 in immune cells [22]. On the other hand, Nfat5 was shown to regulate the expression of several collagen subtypes [23] and chondrogenic differentiation dependent on Sox9 [23], a key transcription factor also in the development of fibrosis [11]. Previous studies show that Sox9 expression is up-regulated by Tgf $\beta 1$ [12] and Tak1 [13].

Tgf $\beta$ is decisive in the triggering of fibrosis of the kidney [3]. Tgf $\beta$ may be effective through serum- and glucocorticoid-inducible kinase 1 (Sgk1) and Akt [24]. Sgk1 expression is sharply up-regulated by cell shrinkage [24]. Tgf $\beta$ significantly contributes to the stimulation of renal fibrosis following UUO [4]. Sgk1 is at least in part effective by phosphorylating glycogen synthase kinase 3 (Gsk-3) [14], which is accomplished by Sgk and Akt isoforms [25].

$\mathrm{NH}_{4} \mathrm{Cl}$ similarly interferes with Tgf $\beta 1$ signaling in vascular tissue during hyperphosphatemia [8]. Moreover, renal dysfunction following 5/6 nephrectomy is ameliorated by $\mathrm{NH}_{4} \mathrm{Cl}$ treatment [26]. The renoprotective effects of $\mathrm{NH}_{4} \mathrm{Cl}$ drinking solution were independent of phosphate [27]. According to these observations, $\mathrm{NH}_{4} \mathrm{Cl}$ may have beneficial properties in renal disease. On the other hand acidosis has been shown to aggravate and alkali treatment to delay progression of chronic kidney disease [28, 29].

\section{Conclusion}

Tgf $\beta 1$ signaling leading to renal tissue fibrosis may be counteracted by $\mathrm{NH}_{4} \mathrm{Cl}$ treatment, an observation possibly opening novel therapeutic opportunities.

\section{Abbreviations}

Col1a1 (collagen type I); ECM (extracellular matrix); EMT (epithelial to mesynchymal transition); Fbn (fibronectin); Gapdh (glyceraldehyde 3-phosphate dehydrogenase); Gsk-3 (glycogen synthase kinase 3); Hdac2 (histone deacetylase 2); Il6 (interleukin 6); Nfat5 (nuclear factor of activated T-cells); $\mathrm{NH}_{4} \mathrm{Cl}$ (ammonium chloride); Pai1 (plasminogen activator inhibitor 1); Sgk1 (serum- and glucocorticoid-inducible kinase 1); Smad2 (Sma and Mad (Mothers against decapentaplegic) 2); Sox9 (SRY (sex determining region Y)-box 9); Tak1 (Tgf $\beta$-activated kinase 1); Tgf $\beta 1$ (transforming growth factor $\beta$ 1); Tnf $\alpha$ (tumor necrosis factor $\alpha$ ); TONEBP (Tonicity-Responsive Enhancer Binding Protein); UUO (unilateral ureteral obstruction); $\alpha$-Sma ( $\alpha$-smooth muscle actin). 


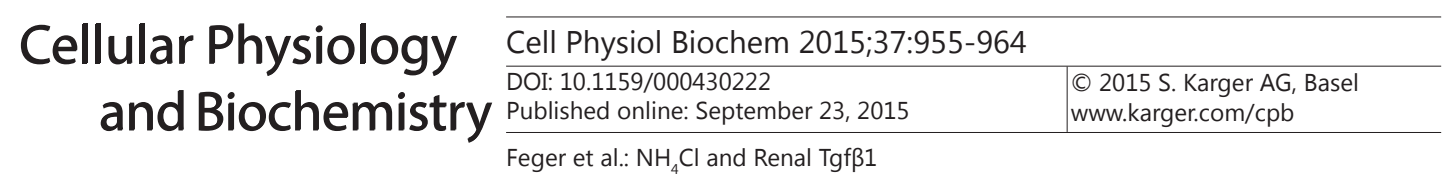

\section{Acknowledgements}

The authors acknowledge the technical assistance of E. Faber and the meticulous preparation of the manuscript by S. Ruebe and T. Loch. This study was supported by the Deutsche Forschungsgemeinschaft and Open Access Publishing Fund of Tuebingen University.

\section{Disclosure Statement}

All authors disclose that they have no potential conflict of interest.

\section{References}

1 Bascands JL, Schanstra JP: Obstructive nephropathy: insights from genetically engineered animals. Kidney Int. 2005;68:925-937.

2 Chevalier RL, Forbes MS, Thornhill BA: Ureteral obstruction as a model of renal interstitial fibrosis and obstructive nephropathy. Kidney Int. 2009;75:1145-1152.

3 Samarakoon R, Overstreet JM, Higgins SP, Higgins PJ: TGF-beta1 --> SMAD/p53/USF2 --> PAI-1 transcriptional axis in ureteral obstruction-induced renal fibrosis. Cell Tissue Res 2012;347:117-128.

4 Cheng J, Truong LD, Wu X, Kuhl D, Lang F, Du J: Serum- and glucocorticoid-regulated kinase 1 is up regulated following unilateral ureteral obstruction causing epithelial-mesenchymal transition. Kidney Int. 2010;78:668-678.

5 Grgic I, Duffield JS, Humphreys BD: The origin of interstitial myofibroblasts in chronic kidney disease. Pediatr Nephrol 2012;27:183-193.

6 Liu Y: New insights into epithelial-mesenchymal transition in kidney fibrosis. J Am Soc Nephrol 2010;21:212-222.

7 Choi ME, Ding Y, Kim SI: TGF-beta signaling via TAK1 pathway: role in kidney fibrosis. Semin Nephrol 2012;32:244-252.

8 Leibrock CB, Alesutan I, Voelkl J, Pakladol Tk, Michael D, Schleicher E, Lamyabi-Moghaddam Z, QuintanillaMartinez L, Kuro-o M, Lang F: NH4Cl Treatment Prevents Tissue Calcification in Klotho Deficiency. J Am Soc Nephrol 2015;in press:

9 Voelkl J, Alesutan I, Leibrock CB, Quintanilla-Martinez L, Kuhn V, Feger M, Mia S, Ahmed MS, Rosenblatt KP, Kuro OM, Lang F: Spironolactone ameliorates PIT1-dependent vascular osteoinduction in klothohypomorphic mice. J Clin Invest 2013;123:812-822.

10 Basque J, Martel M, Leduc R, Cantin AM: Lysosomotropic drugs inhibit maturation of transforming growth factor-beta. Can J Physiol Pharmacol 2008;86:606-612.

11 Hanley KP, Oakley F, Sugden S, Wilson DI, Mann DA, Hanley NA: Ectopic SOX9 mediates extracellular matrix deposition characteristic of organ fibrosis. J Biol Chem 2008;283:14063-14071.

12 Petito RB, Amadeu TP, Pascarelli BM, Jardim MR, Vital RT, Antunes SL, Sarno EN: Transforming growth factor-beta1 may be a key mediator of the fibrogenic properties of neural cells in leprosy. J Neuropathol Exp Neurol 2013;72:351-366.

13 Gao L, Sheu TJ, Dong Y, Hoak DM, Zuscik MJ, Schwarz EM, Hilton MJ, O'Keefe RJ, Jonason JH: TAK1 regulates SOX9 expression in chondrocytes and is essential for postnatal development of the growth plate and articular cartilages. J Cell Sci 2013;126:5704-5713.

14 Voelkl J, Mia S, Meissner A, Ahmed MS, Feger M, Elvira B, Walker B, Alessi DR, Alesutan I, Lang F: PKB/SGKResistant GSK-3 Signaling Following Unilateral Ureteral Obstruction. Kidney Blood Press Res 2013;38:156164.

15 Nowik M, Kampik NB, Mihailova M, Eladari D, Wagner CA: Induction of metabolic acidosis with ammonium chloride $(\mathrm{NH} 4 \mathrm{Cl})$ in mice and rats--species differences and technical considerations. Cell Physiol Biochem 2010;26:1059-1072.

16 Roos A, Boron WF: Intracellular pH. Physiol Rev 1981;61:296-434.

17 Ling H, Ardjomand P, Samvakas S, Simm A, Busch GL, Lang F, Sebekova K, Heidland A: Mesangial cell hypertrophy induced by $\mathrm{NH} 4 \mathrm{Cl}$ : role of depressed activities of cathepsins due to elevated lysosomal $\mathrm{pH}$. Kidney Int 1998;53:1706-1712. 


\section{Cellular Physiology Cell Physiol Biochem 2015;37:955-964

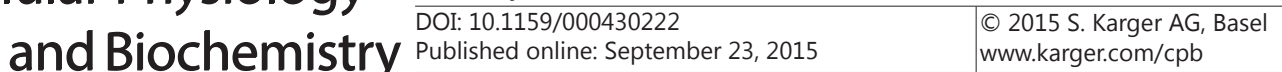 \\ Feger et al.: $\mathrm{NH}_{4} \mathrm{Cl}$ and Renal Tgf $\beta 1$}

18 Kim SI, Kwak JH, Zachariah M, He Y, Wang L, Choi ME: TGF-beta-activated kinase 1 and TAK1-binding protein 1 cooperate to mediate TGF-beta1-induced MKK3-p38 MAPK activation and stimulation of type I collagen. Am J Physiol Renal Physiol 2007;292:F1471-1478.

19 Haussinger D, Gorg B: Interaction of oxidative stress, astrocyte swelling and cerebral ammonia toxicity. Curr Opin Clin Nutr Metab Care 2010;13:87-92.

20 Handler JS, Kwon HM: Cell and molecular biology of organic osmolyte accumulation in hypertonic renal cells. Nephron 2001;87:106-110.

21 Hiyama A, Gogate SS, Gajghate S, Mochida J, Shapiro IM, Risbud MV: BMP-2 and TGF-beta stimulate expression of beta1,3-glucuronosyl transferase 1 (GlcAT-1) in nucleus pulposus cells through AP1, TonEBP, and Sp1: role of MAPKs. J Bone Miner Res 2010;25:1179-1190.

22 Buxade M, Lunazzi G, Minguillon J, Iborra S, Berga-Bolanos R, Del Val M, Aramburu J, Lopez-Rodriguez C: Gene expression induced by Toll-like receptors in macrophages requires the transcription factor NFAT5. J Exp Med 2012;209:379-393.

23 Caron MM, van der Windt AE, Emans PJ, van Rhijn LW, Jahr H, Welting TJ: Osmolarity determines the in vitro chondrogenic differentiation capacity of progenitor cells via nuclear factor of activated T-cells 5 . Bone 2013;53:94-102.

24 Lang F, Bohmer C, Palmada M, Seebohm G, Strutz-Seebohm N, Vallon V: (Patho)physiological significance of the serum- and glucocorticoid-inducible kinase isoforms. Physiol Rev. 2006;86:1151-1178.

25 Sakoda H, Gotoh Y, Katagiri H, Kurokawa M, Ono H, Onishi Y, Anai M, Ogihara T, Fujishiro M, Fukushima Y, Abe M, Shojima N, Kikuchi M, Oka Y, Hirai H, Asano T: Differing roles of Akt and serum- and glucocorticoid-regulated kinase in glucose metabolism, DNA synthesis, and oncogenic activity. J Biol Chem. 2003;278:25802-25807.

26 Jara A, Felsenfeld AJ, Bover J, Kleeman CR: Chronic metabolic acidosis in azotemic rats on a high-phosphate diet halts the progression of renal disease. Kidney Int 2000;58:1023-1032.

27 Jara A, Chacon C, Ibaceta M, Valdivieso A, Felsenfeld AJ: Effect of ammonium chloride and dietary phosphorus in the azotaemic rat. I. Renal function and biochemical changes. Nephrol Dial Transplant 2004;19:1986-1992.

28 Loniewski I, Wesson DE: Bicarbonate therapy for prevention of chronic kidney disease progression. Kidney Int 2014;85:529-535.

29 Phisitkul S, Hacker C, Simoni J, Tran RM, Wesson DE: Dietary protein causes a decline in the glomerular filtration rate of the remnant kidney mediated by metabolic acidosis and endothelin receptors. Kidney Int 2008;73:192-199. 